Recent Trends of Electrowinning of Rare Metals

\title{
Takeo OKI
}

表 1 レアメタルとその利用

\section{1.はじめに}

レアメタルは希有金属とか特殊金属などといわれてい る。乙れについては学術的あるいは産業技術的用語とし ての定義はあまり明確ではない。地球上での天然の存在 量がきわめてまれであるとか, 地球上での存在量は多い けれどあその金属を抽出するだけの濃度もなく，経済性 のある品位の鉱石が少ないむの，また化学的物理的に純 粋な金属として抽出することが極めて困難である。更に 抽出された金属を利用するだけの用途が少なく，物性む 明らかでないため未開発であったあのなどをいう。具体 的には，バリウム，ベリリウム，ビスマス，コバルト， クロム, ガリウム，ゲルマニウム，リチウム，モリブデ ン, ニオブ, ニッケル, インジウム, レアアース, セレ ン，シリコンストロンチウム，タンタル，テルル，チタ ン, バナジウム, タングステン, ジルコニウム, ハフニ ウム等を含む概念である。またクリティカルエレメント とあいわれる。

レアメタルは，先端産業といわれている殆んどすべて の分野に重要な役割を果すようになった。電子工業，情 報産業, エネルギー産業, 航空宇宙産業, 輸送産業, 化 学, 機械その他すべての産業といってよいほど, レアメ タルは関与しているといって過言ではないし，また今後 益々その重要性が増加すると思われる。レアメタルは, 量産される金属とは異なり，一般的な需要の量からゆう と少ないしまた，技術の発展展開によってその必要量の 変動や急変がある。先端産業の盛んな日本の消費比率は 高い。またこの価格の変動も大きい。これらは低品位鉱 石の経済的処理技術の開発，レアメタル資源の開発，資 源りサイクル技術開発などにより，その重要性は更にま すととであろう。(表 1)

このようなレアメタルはすぐれた需要特性をすつが,

* 昭和60年11月 12 日本会第75回例会において発表

** 名古屋大学工学部

昭和 60 年10月 2 日受理

\begin{tabular}{|c|c|}
\hline $\mathrm{Li}$ & ブラウン管添加用, リチウム電池, 合金添加 \\
\hline $\mathrm{Be}$ & $\begin{array}{l}\text { 原子炉減速材, 合金用 }(\mathrm{Al}, \mathrm{Cu}), \mathrm{X} \text { 線空材, ベ } \\
\text { リリヤ磁器 LSI 放熱部品, 絶縁板 }\end{array}$ \\
\hline $\mathrm{B}$ & 合金添加, 高融点金属ホウ化物, 原子炉制御材 \\
\hline $\mathrm{Ca}$ & $\mathrm{Pb}$ 合金 (電池), 脱酸および還元用 \\
\hline $\mathrm{Ti}$ & 航空機材料, 化学装置, 電極 \\
\hline $\mathrm{Ga}$ & $\begin{array}{l}\text { 化合物半導体, 低融点合金, 金属セメント, カ } \\
\text { ラーテレビ, 緑色発光材 }\left(\mathrm{MgO}-\mathrm{Al}_{2} \mathrm{O}_{3}-\mathrm{Ga}_{2} \mathrm{O}_{3}\right) \\
\mathrm{GGG}\left(\mathrm{Gd}_{3} \mathrm{Ga}_{3} \mathrm{O}_{2}\right)\end{array}$ \\
\hline $\mathrm{Ge}$ & トランジスタ, 赤外線フイルター, レンズ \\
\hline As & $\begin{array}{l}\text { 化合物半導体 (GaAs, InAs) 赤外線透過ガラス } \\
\left(\mathrm{As}_{2} \mathrm{~S}_{3}, \mathrm{As}_{2} \mathrm{~S}_{3}\right)\end{array}$ \\
\hline $\mathrm{Se}$ & 乾式複写器, 整流器, 光電池, 赤色着色材 \\
\hline $\mathrm{Zr}$ & $\begin{array}{l}\text { 原子炉被覆材, 耐食材料, 高力電導材料 }(\mathrm{Cu}- \\
\mathrm{Zr}) \text { 超電導材 }(\mathrm{Nb}-\mathrm{Zr})\end{array}$ \\
\hline $\mathrm{Nb}$ & 超電導材料, スーパーアロイ \\
\hline In & 化合物半導体 (InP, Inb, InAs, InGaAs) \\
\hline $\mathrm{Te}$ & $\begin{array}{l}\text { 電子冷凍 }\left((\mathrm{BiSb})_{2} \mathrm{~T}_{3}\right) \text { 光電池 }(\mathrm{CdTe}) \text {, 熱電池 } \\
(\mathrm{PbT})\end{array}$ \\
\hline $\mathrm{RE}$ & $\begin{array}{l}\text { カラーテレビ螢光材, 磁石, 光学レンズ, 水素 } \\
\text { 吸蔵合金 }(\mathrm{La}-\mathrm{Ni})\end{array}$ \\
\hline $\mathrm{Ta}$ & コンデンサー, 超硬工具 \\
\hline $\mathrm{Tl}$ & 赤外線分光（ヨウ化物） \\
\hline
\end{tabular}

供給面においては，国内では殆んど産出されないので， 国際的にも南アフリカ等の政情不安な地域に偏在してい る。技術面においてあ, 需要構造が多品種少量であるて とに加えて，レアメタルの純度，形態等が多様であるた め経済的規模での製鍊が困難であり，まだ，選鉱製錬技 術が確立されていないものも多い。

\section{2. 電解法の位置}

レアメタルを製鍊する方法は大きくわけて，(1)乾式還 元法と(2)電解法とが考えられる。

(1)の乾式還元法に属するものに, マグネシウムやカル シウムなどによる金属還元法と炭素による還元法などが 
よく使用されている方法である。例えば

$$
\begin{aligned}
\mathrm{B}: \quad \mathrm{B}_{2} \mathrm{O}_{3}+\mathrm{Mg} \rightarrow \mathrm{B}+\mathrm{MgO}, \mathrm{BCl}_{3}+\mathrm{H}_{2} \rightarrow \mathrm{B}+\mathrm{HCl} \\
\mathrm{Cr}: \quad \mathrm{Cr}_{2} \mathrm{O}_{3}+\mathrm{Al} \rightarrow 2 \mathrm{Al}+\mathrm{Al}_{2} \mathrm{O}_{3}, \\
\mathrm{Cr}_{2} \mathrm{O}_{3}+3 \mathrm{C} \rightarrow 3 \mathrm{Cr}+3 \mathrm{CO}
\end{aligned}
$$

$\mathrm{Ta}, \mathrm{Nb}: \quad \mathrm{Ta}_{2} \mathrm{O}_{5}+\mathrm{Al} \rightarrow \mathrm{Ta}+\mathrm{Al}_{2} \mathrm{O}_{3}$,

$$
\mathrm{Nb}_{2} \mathrm{O}_{5}+\mathrm{Al} \rightarrow \mathrm{Nb}+\mathrm{Al}_{2} \mathrm{O}_{3}
$$

$\mathrm{Ge}: \mathrm{GeO}_{2}+\mathrm{H}_{2} \rightarrow \mathrm{Ge}+\mathrm{H}_{2} \mathrm{O}$

$\mathrm{Hf}, \mathrm{Zr}: \mathrm{HfCl}_{4}+\mathrm{Mg} \rightarrow \mathrm{Hf}+\mathrm{MgCl}_{2}$,

$$
\mathrm{ZrCl}_{4}+\mathrm{Mg} \rightarrow \mathrm{Zr}+\mathrm{MgCl}_{2}
$$

In, $\mathrm{Ga}: \quad \mathrm{In}^{3+}+\mathrm{Zn} \rightarrow \mathrm{In}+\mathrm{Zn}^{2+}$,

$$
\mathrm{Ga}^{3+}+\mathrm{Al} \rightarrow \mathrm{Ga}+\mathrm{Al}^{3+}
$$

$\mathrm{Pt}$ 属: 塩化白金属酸アンモン数の $\mathrm{H}_{2}$ 還元

$\mathrm{Pu}: \mathrm{PuF}_{4}+\mathrm{Ca} \rightarrow \mathrm{Pu}+\mathrm{CaF}_{2}$

レアーアース：塩化物のカルシウム還元, 酸化物の金属還元法

$\mathrm{RECl}_{3}+3 \mathrm{Ca} \rightarrow 3 \mathrm{CaCl}_{2}+2 \mathrm{RE}$

(F)

$\mathrm{Te}: \mathrm{TeO}_{2}+\mathrm{C} \rightarrow \mathrm{Te}+2 \mathrm{CO}$

$\mathrm{Th}: \mathrm{ThCl}_{4}+\mathrm{Na} \rightarrow \mathrm{Th}+\mathrm{NaCl}$,

$$
\mathrm{ThCl}_{4}+\mathrm{Na}-\mathrm{Hg} \rightarrow \mathrm{ThHg}+\mathrm{NaCl}
$$$$
\mathrm{ThO}_{2}+\mathrm{Ca} \rightarrow \mathrm{Th}+2 \mathrm{CaO}
$$

$\mathrm{Ti}: \mathrm{TiCl}_{4}+\mathrm{Mg} \rightarrow \mathrm{Ti}+\mathrm{MgCl}_{2}$,

$$
\mathrm{TiI}_{4} \rightarrow \mathrm{Ti}+2 \mathrm{I}_{2}
$$

$\mathrm{W}: \mathrm{WO}_{3}+\mathrm{C} \rightarrow \mathrm{W}+\mathrm{CO}, \mathrm{WO}_{3}+\mathrm{H}_{2} \rightarrow \mathrm{W}+\mathrm{H}_{2} \mathrm{O}$

$\mathrm{U}: \mathrm{UO}_{3}+\mathrm{Ca} \rightarrow \mathrm{U}+\mathrm{CaO}, \mathrm{UF}+\mathrm{Mg} \rightarrow \mathrm{U}+\mathrm{MgF}_{2}$

$\mathrm{V}: \mathrm{V}_{2} \mathrm{O}_{3}+3 \mathrm{Ca} \rightarrow 2 \mathrm{~V}+3 \mathrm{CaO}$,

$$
\mathrm{V}_{2} \mathrm{O}_{5}+\mathrm{Al} \rightarrow \mathrm{V}+\mathrm{Al}_{2} \mathrm{O}_{3}
$$

$\mathrm{Y}: \quad 2 \mathrm{YF}_{3}+3 \mathrm{Ca} \rightarrow 2 \mathrm{Y}+3 \mathrm{CaF}_{2}$

\section{などがあげられる。}

これに比して電解法は(1)の方法やそれに準ずる方法で は還元しにくいか，あるいは電解の方がより有効である 時, またはこれにより高純化精錬が出来るなどの利点が ある時に使用される。電解法には水溶液電解法と溶融塩 電解法が主に使用され，水素発生と競争しうる金属，す なわち，水素平衡電位より貴な金属や，水素過電圧の大 きいむのは水溶液電解で, その他のあのは主に溶融塩電 解法が採用される。ここではこの電解法についてのその 方法論とその動向について論じてみたい。

\section{3. レアメタルの電解法}

電解法には電解採取法と電解精製法があり，それぞれ 主に水溶液電解法および溶融塩電解法がある。各レアメ タルに関して記すと，

$\mathrm{Be}: \mathrm{BeCl}_{2}+\mathrm{NaCl}$ (溶融塩),

$2 \mathrm{BeO} \cdot 5 \mathrm{BeF}_{2}+\mathrm{BaF}_{2}$ (溶融塩)

B : $\mathrm{B}_{2} \mathrm{O}_{3}+\mathrm{MgO}, \mathrm{Na}_{2} \mathrm{O}+\mathrm{B}_{2} \mathrm{O}_{3}\left(\mathrm{MgF}_{2}\right)$,

$\mathrm{KCl}-\mathrm{KF}-\mathrm{B}_{2} \mathrm{O}_{3}$,
$\mathrm{KCl}-\mathrm{KBF}_{4}\left(+\mathrm{B}_{2} \mathrm{O}_{3}\right)$, (溶融塩)

$\mathrm{Cr}: \mathrm{Cr}_{2}\left(\mathrm{SO}_{4}\right)_{3} \cdot \mathrm{Al}_{2}\left(\mathrm{SO}_{4}\right)_{3}, \mathrm{CrO}_{3}+\mathrm{H}_{2} \mathrm{SO}_{4}$, (水溶液)

$\mathrm{Nb}, \mathrm{Ta}: \mathrm{K}_{2} \mathrm{TaF}_{7}, \mathrm{~K}_{2} \mathrm{NbF}_{7}$ (溶融塩),

$\mathrm{Ta}_{2} \mathrm{O}_{5}+\mathrm{K}_{2} \mathrm{TaF}_{7}$

$\mathrm{Ga}: \mathrm{NaGaO}_{2}, \mathrm{GaCl}_{3}$ (水溶液)

In : $\mathrm{InCl}_{3}, \mathrm{In}_{2}\left(\mathrm{SO}_{4}\right)_{3}$ (水溶液)

$\mathrm{Mn}$ : $\mathrm{MnSO}_{4}$, (水溶液)

レアーアース: La, Ce, Pr, Nd, Pm, Sm, Eu, Gd, Tb, by, Er, Tm, Tb, Ln, $\mathrm{Y} . \mathrm{RECl}_{3}$ (溶融塩)

$\mathrm{Tl}$ : $\mathrm{Tl}$ 硫酸塩 (水溶液)

Th: $\mathrm{NaCl}-\mathrm{KCl}-\mathrm{ThCl}_{4}, \mathrm{ThF}_{4}-\mathrm{KF}$ (溶融塩)

$\mathrm{Ti}: \mathrm{TiCl}_{2}, \mathrm{TiCl}_{3}, \mathrm{TiF}_{6}{ }^{2-}$ (溶融塩)

$\mathrm{U}: \mathrm{KUF}_{5}+\mathrm{NaCl}, \mathrm{UCl}_{3}+\mathrm{UF}_{4}+\mathrm{LiCl}$ (溶融塩)

$\mathrm{Zr}: \mathrm{K}_{2} \mathrm{ZrF}_{6}+\mathrm{NaCl}-\mathrm{KCl}$ (溶融塩)

以上概略をのべたようにレアメタルは多種類複雑であ るので, こてでは例として水溶液の電解法としての代表 を現状重要なものであるガリウム, インジウムの電解製 精錬についてのべ, 又溶融塩法としては二オブ，タンタ ルの溶融塩電解法およびレアアースの電解法をあげて, レアメタルの電解法の動向についてふれたい。

\section{4. 亜鉊焼鉱浸出残查からのガリウム， インジゥムの回収}

乙の浸出残査は浸出工程, 脱銅工程, 中和工程, 脱鉄 工程をへている。乙のときの中和工程から生ずる第 2 中 和石高をガリウム原料とする。

浸出工程 : $\mathrm{ZnFe}_{2} \mathrm{O}_{4}+2 \mathrm{H}_{2} \mathrm{SO}_{4}+\mathrm{SO}_{2}$

$$
\rightarrow \mathrm{ZnSO}_{4}+2 \mathrm{FeSO}_{4}+2 \mathrm{H}_{2} \mathrm{O}
$$

こ〉で $\mathrm{Ga}$, In は95\%以上の浸出率で溶液 中にくる。

脱銅工程 : 硫化水素を用いて, $\mathrm{Ag}, \mathrm{Cu}$ を回収する工 程で，Cu を完全に除去し，ガリウム，イ ンジゥムを硫化物にならないようにする。

中和工程 : 第 1 中和工程- $-\mathrm{CaCO}_{3}$ で中和し, $\mathrm{pH}=$ 1 とし, $\mathrm{Ga}$ や In が $\mathrm{CaSO}_{4}$ と共沈しない ようにする。

第 2 中和工程 $-\mathrm{pH}=4.0 \sim 4.2$ とし, $\mathrm{Ga}$, In 等のレアメタルを回収すると同時 に亜鉛電解に有害な金属 $\mathrm{Ge}, \mathrm{As}, \mathrm{Sb}$ を共 沈除去する。乙の沈殿は水力分級により石 高と水酸化物とに分離し, ガリウム, イン ジウムの高品位化を計る。

脱鉄工程 $: \mathrm{Fe}^{2+}$ を酸素で酸化してへマタイトとして 沈潵除去する。この工程で, $\mathrm{Ga}$ は鉄と共 に共沈するが, インジゥムは若干しか沈潵 しない。この性質を利用してインジウムの 
回収率の向上をはかる。

上の工程の第 2 中和残査を原料としてガリウムおよび インジゥムを回収している。浸出と不純物除去工程, ガ リウム・インジウムの分離濃縮, ガリウム, インジウム の分離, ガリウムの電解採取, インジゥムの精製の工程 がとられる。

\section{（1）浸出工程}

第 2 中和残査を硫酸で浸出し, 水酸化物を溶出し, 石 毫と分離する。乙の時 $\mathrm{Ga}$, In の浸出率は約 $93 \%$ あるる。 ガリウム・インジウムの水酸化物は鉄等の水酸化物と同 様な特性があり，長時間放置すると難溶性となるためす みやかに浸出を行う必要がある。

（2）脱 銅工程

浸出液に硫化水素を吹き込み, $\mathrm{Fe}^{3+}$ を $\mathrm{Fe}^{2+}$ に還元し， さらに $\mathrm{As}, \mathrm{Cu}, \mathrm{Pb}, \mathrm{Tl}$ 等を硫化物として除去する。乙 のとき液の酸化還元電位を $200 \mathrm{mV}$ vs SCE とし In が硫化物として沈澱するのを防ぐ，さらに共沈した In を回収するために $\mathrm{pH}=0.5$ 程度の硫酸溶液で港物を洗 浄する。

\section{（3）脱アルミニウム工程}

脱吪素後液にアンモニアを吹きてみ, 冷却後アルミニ ウムをアンモニウム明バンとして晶出させて除去する。

\section{（4） ガリウム，インジウムの分離濃縮工程}

ガリウムおよびインジゥムは $\mathrm{pH}=2.5$ 附近より第 3 脂肪酸であるバーサチック10 (Versatic 10) を灯油で希 釈したあのによって抽出が始まり $\mathrm{pH}=3.5$ で終結する。 こ〉でガリウムは $88 \%$ ，インジウムは $92 \%$ 抽出される。 抽出後液は煙灰処理施設に送られ亜鉛やカドミウムを回 収している。

\section{（5） ガリウムとインジウムの分離工程}

ガリウムとインジウムを抽出した溶媒に塩酸を添加し 混合攪拌して，溶媒に含まれていた金属を塩酸相に移行 さす。塩酸相の酸濃度を調整し, エーテルによる抽出を 行いガリウムを抽出し，インジウムおよび他の金属との 分離を行う。又 DP 2 PM $^{2)}$ (Diphenyl-2-Pyridylmethane) によっても行なわれる。

エーテル抽出後の塩酸相に T. B. P-灯油の溶媒を混合 攪拌し, インジゥムの抽出を行い，他の金属との分離を 行う。

\section{（6） ガリウムの電解採取工程}

エーテル相中のガリウムは水で逆抽出を行い, ガリウ ムは水相にうつる。アルカリで $\mathrm{pH}$ をあげて, カリウム 酸ソーダとして固液分離を行い鉄その他の不純物之分離 する。得られた液に硫酸を加えて $\mathrm{pH}=6$ として水酸化 ガリウムの沈澱を生成させ沪別後, カ性ソーダを加えて 溶解し, ガリウムの電解原液とする。電解はアノードと
カソードにステンレス板を用い電流密度 $2000 \mathrm{~A} / \mathrm{m}^{2}$, 温 度 $30^{\circ} \mathrm{C}$ 以上の条件で電解を行い, 得られる金属ガリウム は電解時は液体金属で得られる (m. p. $\left.29.75^{\circ} \mathrm{C}\right) 。 99.99$ \%のものが得られる。

\section{（7）インジウムの精製工程}

TBP 相に含まれているインジゥムを水で逆抽出し, インジゥムを水相に移し, 次の工程で金属インジウムを 回収精錬する。

置換工程: 水相にアルカリを添加し, $\mathrm{pH}=2.5$ とし, $\mathrm{pH}$ をいじしながら $70^{\circ} \mathrm{C}$ で亜鉊あるいはアルミニウム 置換を行い, インジウムをスポンジインジウムとして採 取する。

溶融工程 : スポンジ状インジゥムはカ性カリをフラッ クスとして溶融し，アノードに鋳込む。

電解工程: 硫酸酸性溶液中でインジゥムアノードと, ステンレスカソードを用いて，2段階にわけて電解精製 を行う。第 1 段電解は $220 \mathrm{~A} / \mathrm{m}^{2}$ で行い, 第 2 段電解は $105 \mathrm{~A} / \mathrm{m}^{2}$ で電解精製を行い，99. 99\%の金属インジゥム がえられる。

\section{5. レアアース金属の電解法}

トン単位で溶融塩電解で作られているすのはミッシュ メタルのみである。(52 Ce, $18 \mathrm{Nd}, 5 \mathrm{Pr}, 1 \mathrm{Sm}, 24$ (La etr))

使用される $\mathrm{RECl}_{3}$ はクロリネーションによって作ら れる。

含水塩化物は加熱あるいは融解によって脱水する。乙 のとき $\mathrm{NH}_{4} \mathrm{Cl}, \mathrm{NaCl}, \mathrm{CaCl}_{2}$ などと共に融解すると特に よい。また最近無水塩化物は乾式塩化法によって作られ るようになった。

$$
\mathrm{RE}_{2} \mathrm{O}_{3}+3 \mathrm{Cl}_{2}+3 \mathrm{C} \rightarrow 2 \mathrm{KECl}_{3}+3 \mathrm{CO}
$$

電解液は $\mathrm{RECl}_{3}+\mathrm{NaCl}$ を主として用いる。 $800^{\circ} \mathrm{C}$ $900^{\circ} \mathrm{C}$ で電解する。

レアーアース元素はその化学的性質が相互に異常に類 似しているため, 相互の分離は非常に困難である。レア メタルの分離法のおあなむのは,

（1）原子価変化法

(i) 酸化法 $\mathrm{Ce}^{3+} \rightarrow \mathrm{Ce}^{4+}, \mathrm{Pr}^{3+} \rightarrow \mathrm{Pr}^{4+}, \mathrm{Tb}^{3+} \rightarrow \mathrm{Tb}^{4+}$

(ii) 還元法 $\mathrm{Eu}^{3+} \rightarrow \mathrm{Eu}^{2+}, \mathrm{Sm}^{3+} \rightarrow \mathrm{Sm}^{2+}$, $\mathrm{Yb}^{3+} \rightarrow \mathrm{Yb}^{2+}$

（2）分別法

（1）分別結晶法

(ii）分別沈澱法

(iii) 分別熱分解法

(iv) 錯塩の分別分解法

(3) 溶媒抽出法

(4) イオン交換法 
これらのうち原子価変化法は異原子価をとりうる元素 に適用して効果的なむので，ての中であ安定な $\mathrm{Ce}^{4+}$, $\mathrm{Eu}^{2+}$ の分離精製に常用されている。例えばまず多量に 含まれているセリウムを 4 価侄化して分別沈澱などの 方法で分離し，その他の元素は溶媒抽出法によって分離 する。分別法は古典的方法で, レアメタルの分離の工業 的利用は困難といえる。

今日, 工業的に用いられている分離法はイオン交換法 と溶媒抽出法。レアアースの分離には隣接した元素間の 分離係数 SF (Separation Factor) の大きな溶媒ほど有利 である。溶媒には有機の中性りン酸塩, 酸性リン酸塩, カルボン酸監, アミン塩, アンモニウム塩など各種ある が, 現在よく使用されているのは, TBP と D2EHPA である。隣接した元素間の分離係数はお〉よそ TBP に おいては1.3〜1.8，D2EHPA において2.0〜2.5が実用 的な值である。溶剤はキシロールやケロシンを主に使用 する。

例としてカドリニウム $(\mathrm{Gd})$ の溶融塩電解3) において 80 モル\%LiCl-18モル\%LiF-2モル\% $\mathrm{GdF}_{3}$ で電析 $\mathrm{Gd}$

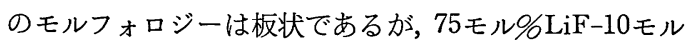

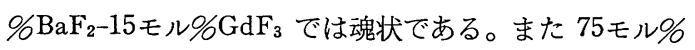
$\mathrm{LiF}-10 モ ル \% \mathrm{GdF}_{3}$ では針状になるととが見出されてい

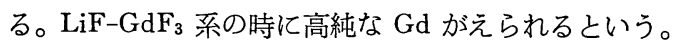

$\mathrm{LiF}-\mathrm{BaF}_{2}-\mathrm{GdF}_{3}$ 系では電流密度が $1.6 \mathrm{~A} / \mathrm{cm}^{2}$ 以上に なると塊状から針状に変化する。電流効率は $\mathrm{LiF}_{\mathrm{iFdF}}$ 系が最むよいとゆう結果をえている。乙れは $\mathrm{GdF}_{3}$ の濃 度が大きいためかも知れない。この様に条件海感であ る。

\section{6. $\mathrm{Ta}$ および $\mathrm{Nb}$ の電解法}

$\mathrm{Ta}$ の溶解塩電解法は基本的には $\mathrm{KF}-\mathrm{NaF}-\mathrm{K}_{2} \mathrm{TaF}_{7}$ 系を 700 $800^{\circ} \mathrm{C}$ で電解するととを原理としている。 との時酸化物をフィードすることがある。この電解液 系は $\mathrm{KF}-\mathrm{K}_{2} \mathrm{TaF}_{7}, \mathrm{~K}_{2} \mathrm{TaF}_{7}-\mathrm{Ta}_{2} \mathrm{O}_{5}, \mathrm{KF}-\mathrm{K}_{2} \mathrm{TaF}_{7}-\mathrm{Ta}_{2} \mathrm{O}_{5}$, $\mathrm{K}_{2} \mathrm{TaF}_{7}-\mathrm{Ta}_{2} \mathrm{O}_{5}-\mathrm{KCl}-\mathrm{KF}, \quad \mathrm{KCl}-\mathrm{KF}-\mathrm{K}_{2} \mathrm{TaF}_{7}, \quad \mathrm{KCl}-$ $\mathrm{K}_{2} \mathrm{TaF}_{7}-\mathrm{Ta}_{2} \mathrm{O}_{5}$ などが用いられる。これらの方法で得ら れる $\mathrm{Ta}$ 金属は高純で, 炭素アノードを用いたときです $0.06 \mathrm{C}, 0.02 \mathrm{Fe}, 0.01 \mathrm{Ni}$, などを含む。 $\mathrm{Ta}_{2} \mathrm{O}_{5}$ はアノー ド効果を防ぐことが出来る。

との系の通常の電解すなわちアノード効果がない時に
は

$$
\begin{gathered}
2 \mathrm{TaOF}_{5}^{2-} \rightarrow 2\left(\mathrm{TaOF}_{5}\right) \\
2\left(\mathrm{TaOF}_{5}\right)=2 \mathrm{O}+2 \mathrm{TaF}_{5} \\
2 \mathrm{O}+\mathrm{C} \rightarrow \mathrm{CO}_{2} \\
2 \mathrm{TaF}_{5}+4 \mathrm{~F}=2 \mathrm{TaF}_{7}{ }^{2-}
\end{gathered}
$$

のようなアノード反応があるとあいえる。

電解反応としては

$$
\mathrm{K}_{2} \mathrm{TaF}_{7}+5 \mathrm{Cl}^{-} \rightarrow 2 \mathrm{~K}^{+}+7 \mathrm{~F}^{-}+5 / 2 \mathrm{Cl}_{2}+\mathrm{Ta}
$$

で示される。

電解中に次の様な反応により電流損失が考えられる。

$$
\begin{array}{ll}
(-): & \mathrm{Nb}^{5+}+2 \mathrm{e} \rightarrow \mathrm{Nb}^{3+} \\
(+): & \mathrm{Nb}^{3+} \rightarrow \mathrm{Nb}^{5+}+2 \mathrm{e}
\end{array}
$$

電解溶液中の $\mathrm{Nb}$ の量が低濃度のとき, 或は比較的高い 電流密度のときには $\mathrm{Nb}^{3+}$ がカソードで生成され，殆ん ぞすぐ金属にまで還元される。Nb の量の少な溶からは 長い樹技状晶が得られる。

工業的に $\mathrm{Ta}$ や $\mathrm{Nb}$ の製造は, 溶融塩電解法かアルカ リ金属還元であるが, 電解法は直接電気エネルギーを利 用出来るが，装置が複雑となりがちである。ナトリウム などによる還元法は装置は簡単であるが，還元剤のナト リウム金属などは電解によって再生されなければならな い。

生成物の純度は共に高く，主にフィード物質によって 決まると同時に洗涤に充分注意をはらう必要がある。乙 の電解法と還元法の大きな差は生成分の粒子経が異なる。 電解法のものは大きく，樹技状や密な粒子であるが，ナ トリゥム還元法のあのは非常に細かく，しばしばポーラ スである場合が多い。電解法によるものは洗條法が大変 容易である利点がある。

\section{参 考 文 献}

1) Hideki $\mathrm{ABe}$ etal : Recovery of In \& In at Dowa Mining. 4 th Toint Meeting. MMIJ-AIME 1980. Tokyo, 65

2) Hasany, S. M. et al : Solvent Extraction of Ga from $\mathrm{HCl}$ Solution with DP 2 PM : J. Less (Common Metal : 771, 1981). 157

3) Zwilling. G : Fused Salt Electrorefining of Gd, J. Less Common Metals., 78(1981) 109 